Conference paper (Preliminary communication)

UDC: $502.131 .1: 711.4$

https://doi.org/10.18045/zbefri.2019.2.777

\title{
Scrutinizing the Smart City Index: a multivariate statistical approach*
}

\author{
Olga Bogdanov ${ }^{1}$, Veljko Jeremić ${ }^{2}$, Sandra Jednak ${ }^{3}$, Mladen Čudanov ${ }^{4}$
}

\begin{abstract}
The smart city represents a frequently elaborated concept which however comes short in delivering a consistent definition. Nevertheless, almost every description has always been oriented to its technological component, sustainable development policies, and enabling high capacities for learning and innovation. Moreover, the smart city aims at connecting people, information and other city elements using state-of-the-art technologies. As a result, it creates a sustainable, greener city, pushes forward competitive and innovative commerce, and increases overall life quality. The integrated view of a smart city underlines it does not operate in isolation, which is why every subsystem of a city needs to develop its smart component. A wide range of rankings is used to determine the smartness of cities by mapping out the pros and cons of each analysed city. As the way to integrate various indicators into one value which will represent the rank, a composite index approach is most frequently used. Still, composite indexes are usually formed using the equal weight approach, which is heavily criticised in current literature. In this paper, we
\end{abstract}

\footnotetext{
* Received: 01-06-2019; accepted: 17-12-2019

${ }^{1}$ MSc student, University of Belgrade, Multidisciplinary Studies, Rectors Office, Studentski Trg 1 Street, 11000 Belgrade, Serbia. Scientific affiliation: sustainable development, public policy, socio-economic development. Phone: +38162592822.E-mail: olgabogdanov94@gmail.com. https://orcid.org/0000-0001-7933-377X.
}

2 Associate Professor, University of Belgrade, Faculty of Organizational Sciences, Jove Ilica Street 154, 11000 Belgrade, Serbia. Scientific affiliation: applied statistics, composite indicators. Phone: +381113950800.E-mail:veljko.jeremic@fon.bg.ac.rs.http://orcid.org/0000-0002-0266-5247.

3 Associate Professor, University of Belgrade, Faculty of Organizational Sciences, Jove Ilica Street 154, 11000 Belgrade, Serbia. Scientific affiliation: economic development, economics of ICT, knowledge (based) economy and energy economics. Phone: +381113950800. E-mail: sandra.jednak@fon.bg.ac.rs.http://orcid.org/0000-0001-7265-1249.

4 Associate Professor, University of Belgrade, Faculty of Organizational Sciences, Jove Ilica Street 154, 11000 Belgrade, Serbia. Scientific affiliation: organisational theory and design, business models, information and communication technologies influences on organisation. Phone:+381113950800.E-mail: mladen.cudanov@fon.bg.ac.rs.https://orcid.org/0000-00016895-6525. 
try to provide added value to the Smart City Index by implementing the statistical post hoc I-distance approach. The procedure enables us to shed some additional light on the issue of sensitivity of cities' rank. The application of post hoc I-distance defines indicators which are most significant for the ranking process. It consequently empowers city decision-makers to improve their performance, with a focus on those particular indicators.

Key words: post hoc I-distance, smart city, sustainable development, technology, integration

JEL classification: $C 38, O 18, O 30$

\section{Introduction}

Smart city, as a new phenomenon, has been defined over the years using multiple measurements, to divide its components and provide a further explanation of it. Many definitions of smart cities are oriented to its technological component (Chamoso et al., 2018; Allam and Newman, 2018), insisting on a particular aspect of it and naming it intelligent city, information city or techno city. In contrary, Albino, Berardi and Dangelico (2015) explain that a smart city cannot possibly be defined just by relying on its technological features. The time that smart city debates and researches focused on this subject were dominated by technological determinism is currently well over. However, the belief that smart technologies will solve significant infrastructural and social challenges is still quite popular and favoured. The appearance of the Internet of Things (IoT) and its potential as "the key technological enabler" (Engelbert et al., 2019) aids this belief. From now on, other components of smart cities' research are introduced like as citizens, quality of living and sustainability (Ismagilova et al., 2019). Silva, Khan and Hand (2018) identify four pillars of the smart city: institutional, physical, social and economic infrastructure, resting atop citizen involvement.

To consider a city "smart" most of its components should be related to each other and altogether represent a well-organised system. The question that raises directly from this is when is a city "smart"? What primary characteristic should a city involve, and in which way they should be presented? Even though interpretations of smart cities that are "technology-driven" represent an essential stage in defining it, they still fail to include the human dimension of cities - that is fundamental (Oliveira and Campolargo, 2015). A city can be considered smart if it uses more efficient services, invests in environmental sustainability and insists on smart energy usages (Girardi and Temporelli, 2017). Many contemporary definitions, explanations and theories are related to this topic, but the majority stress out the significance of the social dimension of smart city and its necessity for the city's development and sustainability. Therefore, this paper will be focused on measuring its social and economic aspects. In particular, special emphasis will be given on the sustainability of a smart city and the issues of so-called "smart governance". 
The purpose of this paper is to explore the concept of the smart city by integrating multiple indicators of its "smartness" into one value that will represent the rank. Composite indicators have become commonly used metrics in the calculation of complex phenomena since the complexity of smartness cannot be captured by using a single measure. Composite indicators are often used to summarise a multidimensional phenomenon (Floridi et al., 2011) by providing a smaller number of variables. Furthermore, one of the main advantages of composite indicators is its possibility of comparison and ranking different entities. Thus, it can be used to initiate public and political discourse (Maricic et al., 2019). This trend is one of the reasons why this type of metrics will be used to examine the smartness of the city. For this paper, we will try to provide added value to the smart city index by applying the statistical post hoc I-distance approach, leading to the most significant factors for the ranking process and enabling focus on those indicators.

The paper organisation is as follows. After the introduction, section 2 presents a literature review of social dimension and sustainability of a smart city and composite indicators. After the presentation of multi-components of smart cities, Sections 3 and 4 discuss methods and indicators that were used to determine smart city government ranking. Section 5 provides results and discussion about the rank of smart cities. The final section summarises the conclusions.

\section{Literature review}

\subsection{Social characteristics of a smart city and human capital}

A city needs to provide substantial investment in human and social capital, as well as in other valuable (mostly technological and infrastructural) resources in order to be considered smart. The ICT infrastructure is a major factor for achieving the smart status of the city, but it is out of high importance to invest in social and human capital (people and citizens) (Cocchia, 2014). Firstly, by using the term human capital, we point out specific skills, knowledge, ideas and capabilities of highly educated people (Rafaj, 2016). Human capital is also defined as the "stock of skills that the labour force possesses" (Goldin, 2015).

On the other hand, social capital represents a slightly different category - it includes people or citizens connection with others, and other social institutions, as well. Both of these two concepts are essential to explain and understand how the smart city is really "made" and what makes its development more likely (Appio et al., 2019). It is fundamental not to forget that, besides its economic and technological dimensions, the city is still "made of" people, its citizens. For an adequate development of all particular components of a smart city educated and socially active human beings are irreplaceable (Vlasenko and Ivanova, 2017). 
Human Smart City paradigm recognises cities smartness in the "capability of cities to include citizen-driven developments together with physical, technical and technological layers" (Rizzo and Deserti, 2014). At this point, since we are considering the social dimension, the human capacity to live "outside of their world" is exceptionally worthy. Making connections outside of their own "world" can embrace the development of a smart city in several ways. Various social factors empower the city's smartness. One of the elements is people with "affinity to lifelong learning, social and ethnic plurality, flexibility, creativity, cosmopolitanism or open-mindedness, and participation in public life" (von Richthofen, Tomarchio and Costa, 2019). People are the leading innovation providers that are in charge of making the smart city more humane, open-minded and comprehensive (Pultrone, 2014). A smart city requires people that are willing to actively participate in public life, make decisions on their own and be in all possible ways creative.

It is reasonably apparent that the smart city requires smart people, but what do we precisely mean by saying, smart people? In terms of critical characteristics of citizens, it is already explained that being social, creative and open-minded is essential. Despite that, there is one other notable feature - education, which is well connected with human capital, creativity and social integration, as well (Capdevila and Zarlenga, 2015). Education is a critical component that undoubtedly creates smart city (Nur, Musaruddinand and Zulkaida, 2018). The existence of knowledge and other educational institutions in smart cities (Heijlen and Crompvoets, 2019) are out of high importance to develop human capital. According to Shapiro, three simple explanations clarify why human capital, acquired through education, is so well-connected to employment growth in big cities. First one highlights that people are willing to live in areas that are characterised by the high quality of life. However, these areas are intended for well-educated people that possess high levels of human capital. These well-educated citizens can provide more significant productivity growth based on their knowledge and previous experience (Shapiro, 2006). Finally, when areas are populated with educated citizens, rapid growth in the economy and quality of life itself is expected (Edvinsson, 2006). Shapiro's last explanation of the connection between human capital and growth in employment relates to politics. More educated citizens have a massive influence on the contemporary political situation, so they are highly involved in the decision-making process (Shapiro, 2006; Edelenbos, van Meerkerk, Koppenjan, 2017). Cardullo and Kitchin (2019) emphasise the role of smart citizenship participation in the development of smart cities. A smart city is, in these terms, an actual representation of a centre of higher education (Winters, 2011), it is "full of skilled workforces" (Glaeser and Berry, 2006). Having all this in mind, we can advocate feedback mechanism between smart cities and smart citizens: first make the second smarter, and vice versa.

While formal citizen education is recognized as necessary for a smart city, intercultural education is also considered within the social component (Liu et al., 
2017). Intercultural education represents a different perspective that is related to cultural diversity in standard education. A smart city should lay on "creative culture that extends beyond diversity and creativity to economic performance and social tolerance" (Nam and Pardo, 2011). It is beyond the limits that are set by races, ethnic groups or nationalities. Besides that, intercultural education considers diversity as a reliable resource, rather than as a weakness that society should overcome (Aguaded-Ramírez, 2017).

The idea of a smart city is based on the process of achieving sustainable development. It can be guaranteed if social capital and contemporary technologies are used in a proper way (Poletti and Michieli, 2018). The broad concept of the smart city also gets along with its environmental component, which is correspondingly highly significant. Discussing smart society could not be possible, without taking the idea of "smart environment" into consideration. It relates to the many factors such as "smart vehicle management system, smart traffic management system, smart waste management system, smart agriculture" (Goel and Kumar, 2018). The environment should be able to "adapt itself to the user needs and to provide customised interfaces to the services available at each moment" (MarsaMaestre et al., 2008). The road to smart city necessarily leads through the integration of technological component and people capacity (Vidiasova et al., 2017). There is a wide variety of examples of how the environmental component can be provided with help from the smart government. Promotion of biking is one, due to the reduction in needed parking space and improvement of ecological friendliness of city hubs like railway station areas (de Wijs, Witte, Geertman, 2016). Authors describe the optimisation of garbage collection, sorting and recycling by employing smart sensors in garbage cans, educating citizens about the importance of recycling as a helpful aid in making this strategy function well (Appio et al., 2019). When it comes to architecture, a commonly named "smart grid" architecture allows the distribution of different systems that optimise the usage of specific sources of energy (Koutitas, 2018). Creating smart environments can be done by combining "a certain number of smart rooms to create a smart building and a certain number of smart buildings and smart outdoor spaces to create a smart city" (Marsa-Maestre, 2008). Ruiz-Romero et al. (2014) argue that a smart grid is one of the prerequisites for the development of a smart city, providing a vide set of technologically advanced functionalities for the citizens.

The crucial component of life in cities is energy, as it provides a wide variety of economic activities and creates a high quality of life. If cities are aspiring to meet public policy objectives, they have to "develop smartly, without disregarding the issues of energy efficiency and sustainability" (Papastamatiou et al., 2017). That is why technological component should not be excluded, since the quality of life can be upgraded by developing and using natural, economic, human and social capitals, and also by using healthy and sustainable building materials (Ercoskun, 2011). 


\subsection{Sustainability of a smart city}

Sustainable development is highly connected with the social dimension of smart cities since it cannot be expected or reached without people that are actively participating in making it possible. In recent decades, sustainable development has become a popular concept that almost everyone is familiar with (Fratianni and Savona, 2016). However, in the available literature, there still is a wide variety of definitions and ways of considering it. Summarising other descriptions, Brundtland (1987) claims that sustainable development is "development that meets the needs of the present without compromising the ability of future generations to meet their own needs". According to Brundtland, there are four dimensions of sustainable development: satisfying human needs, safeguarding ecological sustainability, encouraging intra-generational and inter-generational equity; and all of these dimensions represent the importance of social elements (Jeekel, 2017).

During the recent decade, the whole idea of sustainable development (Bojkovic et al., 2019) has become popular, but then also complicated and sometimes even contradictory, since the cities sustainability can be presented as "multidimensional concept that includes economic, social and political dimensions" (Batagan, 2011). Nowadays, societies are faced with the problem when trying to obtain economical, social and ecological sustainability (Robinson, 2004). Still, smart cities are likely to influence or improve the process of social development by information and communication technologies that support connections and collaborations, a smart city is seen as "an icon of a sustainably liveable city" (Nam and Pardo, 2011). However, productivity growth in one country does not depend as much on technology, rather than on human capital, knowledge creation and diffusion, and creativity, which are found to be central components of the innovation (OECD, 2015).

The question that remains is, how can people assist in the process of making society more sustainable? The collapse of the previous city-based civilisations, e.g. the Mesoamerican cultures or the Roman empire give critical lessons on the importance of sustainability and ideas for the application of modern tools to prevent repeated mistakes. It is crucial to empower these citizens to influence choices for development and participate in decision-making. Social networks, also, highly participate in this procedure by giving people ability to share some of their particular interest and, on the other hand, providing all possible information and data collections (Monfaredzadeha and Kruegerb, 2015). There is a straightforward way that will enable hearing citizens "voice" - internet and its online platforms. Through online participation, people can evaluate suggestions within administration and politics to develop some of the crucial aspects of social sustainability: equity, community and urbanity (Yiftachel and Hedgcock, 1993). This way, citizens will be provided with the opportunity to make their suggestions, propose ideas and share their experience and previous knowledge for the benefit of the local governments. 
That way, there will be no possibility that citizens participation will be ignored and neglected (Matos et al., 2017).

Consequently, appropriate policies that are focused on engaging citizens represent the primary key that will make smart cities successful. Authors recognise "smart people" among the main dimensions of the smart city (Lombardi et al., 2012). Therefore, a smart city can be seen as an "efficient, technologically advanced, green and socially inclusive city" (Vanolo, 2014).

\subsection{Economics and governance of the smart city}

In recent decades, smart governments have become the bearers of transformations in the economy since modern industries have effectively replaced heavy industries and manual work and have created new business models (Anttiroiko et al., 2014). Many new trends were established through developing a smart economy, which is different from the classic economic globalisation. It can be seen as one of the indicators of neoclassical globalisation that is characterised by new philosophies and management activities, in which urban problems are seen as opportunities for profit and business investments (Anand and Navío-Marco, 2018). Snieska and Zykiene (2014) identify these characteristics of future smart city related to its governance and economy: internationally accessible, economically vital, innovative, safe, healthy, attractive, comfortable, inhabited with responsible society.

Economic problems imposed before smart cities to overcome include related challenges of establishing new businesses, reduction of unemployment rates, new job openings, increasing the attractiveness in the region, competitive advantage creation and productivity improvement (Alkis et al., 2019). However, the question remains whether smart cities benefit more to the citizens of higher socioeconomic groups, instead of embracing the needs of the more general population as well (Yigitcanlar et al., 2018). Developing a city with smart components that will have an ability to deal with these issues is not a natural part since people are not only consumers of public services, they also actively participate in creating them (Dustdar and Scekic, 2018). Co-creation of public services (Osborne, 2018) is an exciting approach dealing with this issue - cooperation between the community, and the governing parties can solve capital issues (Mussi and Tortato, 2018). The situation is not that "bright" when it comes to regulatory institutions that should be established to provide fair competition and manage the market in the right way. It is still essential to deal with the problem of "large players" that are currently dominating all markets and represent an obstacle when it comes to employment of young generations (Han and Hawken, 2018). Besides that, this approach favours monopolistic competition that certainly does not bring any excellent opportunities for "small players" (Anand and Navío-Marco, 2018). Still, inventive cities represent a "natural magnet" for open innovation projects, which enables citizens to take part 
in them, such as the example of "living lab" in Nice, France. This "living lab" has been created within a green mobility project and involved a range of actors, such as the regional institution for air measurement quality, the institution dealing with the IoT solutions, citizens etc. (Schaffers et al., 2011).

Governance plays an undoubtedly substantial role in making and maintaining the sustainability of smart cities. A smart city is, in an organisational sense, a learning organisation, and governance needs to adopt the learning organisation principles (Senge 2006). In developed smart cities, governments role is to manage multiple mechanisms of urban development, provided well-organised and integrated strategies of local development (Azzari et al., 2018). Smart governance is essential for defining smart cities, which is why it needs to depend on the process of decisionmaking and social participation in that procedure (Hammad and Ludlow, 2016).

The government plays a vital role in managing information flow between multiple actors and stakeholders, as well as in processing data that are related to smart city initiatives (Bouzguenda, Alalouch and Fava, 2019). It needs to provide its citizens with the ability to participate in public life and enable them to make meaningful choices regarding social issues. According to that, smart governance must cope with the conditions and requirements, i.e. the complexity and uncertainty of society (Scholl and Scholl, 2014). Still, challenges of a smart city consist of many difficulties since the participatory government is a relatively contemporary phenomenon, which means many generations are not familiar with it. The smart government should aspire changes that will lead modern society to a smart community, aiming for the "citizen-centric" approach (Sharma et al., 2014). These significant changes are outcomes of the smart government, and those are the economic performance, citizen-centric services, social exclusion, environmental performance, e-government interaction, city branding, efficient government, integral vision and collaborative governance (Anthopoulos, and Reddick, 2016; Caragliu, Del Bo and Nijkamp, 2011). Change dynamics are likely to increase in the future (Cudanov et al., 2019), providing more vibrant development of the smart cities. The most important of all dimensions mentioned is the interaction with citizenship, as they represent the underlying structure of smart-sustainable development (Yigitcanlara and Kamruzzaman, 2018). Consequently, providing transparency in decision making and creating citizen-centric growth aids to the involvement of citizens in governance (Kumar et al., 2016).

\subsection{Composite indicators}

Indicators represent pieces of information or analytical tools that summarise some distinctive characteristic of a system (Zhang and Zhou, 2018). By taking into account a multidimensional aspect of a particular phenomenon, policymakers introduced the need for composite indicators. Composite indicators are mostly used 
when it comes to complex phenomena that cannot be encapsulated by using a single variable (Maricic et al., 2019). They enable not only more fluid understanding of the particular multidimensional phenomenon (Saisana and Tarantola, 2002) but offer a strong possibility of comparison and ranking among units_Rondinella and Grimaccia, 2017).

Numerous benefits of using composite indicators have been elaborated in the literature (Giambona and Vassallo, 2014). In a nutshell, data analysis and interpretation of the results is easy; composite indicators enable a clear-cut ranking of observed entities and comparing their performance over time (Mazziotta and Pareto, 2016). Besides the pros of the composite indexes, it is worth emphasising some particular hurdles when pushing forward the concern of composite indicator. In particular, composite indicators may be misleading if established by taking 'incompatible' or 'naive' choices in the process of weighting and aggregation (Greco, 2019). Three often cited slippery stones of composite indicator creation are the method of normalisation, then weighting approach and finally aggregation (Becker et al., 2017). Although normalisation (transforming diverse units to standard or unit-less quantities) enables a foundation for the process of aggregation, it elicits tradeoffs within the analysis (Pollesch and Dale, 2016). When it comes to weighting, preferably weights are supposed to demonstrate the contribution of observed indicator to the overall composite indicator. The composite indicator creators can give weight to indicators which will reflect their importance to the overall composite indicator (Decancq and Lugo, 2013). This attribute is why it is relatively essential to choose the right weighting scheme (Černá et al., 2017). Different classes of approaches in assigning weights (data-driven, normative and hybrid) have been introduced into literature (Sánchez-González \& GarcíaFernández, 2019) with each being scrutinised (Lagravinese et al., 2019). Same applies for aggregation, with full/zero/partial compensation being a matter of concern in a wide range of papers (Nardo et al. 2005; El Gibari et al., 2019).

\section{Methodology}

The methodology that we applied in our case study is post hoc I-distance approach, which brought many benefits to the variety of applications previously elaborated (Ivanovic, 1973; Jeremic et al., 2011; Jovanovic et al., 2012; Dobrota et al., 2016; Jednak et al., 2018; Radojicic et al., 2018; Radojicic et al., 2019). I-distance method enables the integration of a range of variables into one variable (total score) which can be used to determine ranks of observed entities. It starts by defining an entity (for instance, city, region, country, etc.) with the lowest values for each of the observed variables (usually, it is a fictive entity). In the next step, the distance of each entity in the dataset from the fictive entity is calculated (Milenkovic et al., 2016). Larger the difference, the better rank of observed entity is noted. Moreover, the method provides 
information about the importance of each compounding variable for the creation of the total score through the correlation coefficient. Furthermore, the post hoc I-distance approach offers an in-depth evaluation of countries' performance (Jeremic et al., 2018). This method excludes the least important indicator in each iteration of the method (Markovic et al., 2016). The least important indicator is the one with the lowest correlation coefficient with the I-distance value. Post hoc I-distance method stops when the average correlation drops (Markovic et al., 2016; Jeremić, 2018), the variability of the composite indicator increases (Savic et al., 2016) or final two variables remain (Jeremic and Martic, 2015).

In our case study, we incorporated the ten variables compounding the composite index into post hoc I-distance procedure. For each iteration, we obtained the ranks of cities and the correlation coefficient of each variable with the total score. In each iteration, the variable which has the lowest influence on the overall score gets eliminated, and the I-distance procedure is repeated until the two final variables are determined. This approach not only enables the possibility to determine which variables are the most important for the ranking procedure but to examine the consistency of ranks for each analysed city as well.

\section{Empirical data and analysis}

For this paper, we have used publicly available data on the global top 50 smart cities. These ranking were acquired from the study Top 50 Smart City Governments which supports the idea that smart cities may develop on three dimensions: scope, scale and integration. Based on this division between crucial aspects, they have chosen ten different factors that were used to determine city Government rankings (Eden Strategy Institute, 2018):

V1. Vision - a well-defined strategy that is necessary to establish smart cities;

V2. Leadership - enthusiastic leadership that provides projects around the city;

V3. Budget - funding of each city;

V4. Financial incentives - participation of the private sector is delivered with this way;

V5. Support programmes - support programs encourage the involvement of private actors;

V6. Talent-readiness - provide smart skills within each city;

V7. People-centricity - people-first design of the future city;

V8. Innovation ecosystems - a scope of engaged stakeholders that can develop meaningful innovations; 
Olga Bogdanov et al. $\bullet$ Scrutinizing the Smart City Index: a multivariate statistical...

V9. Smart policies - provide the right environment for the development of a smart city, in every possible segment - e.g. data governance, protection, urban design;

V10. Track record - already existing experience of a specific government in the implementation of the smart city initiative (Eden Strategy Institute, 2018).

These ten factors have been determined as an essential one for city governments and their ongoing efforts in formulating smart city strategies. The values for each of the factors (variables) ranged from one to five, with five being an indication of a best-in-class commitment to smart city framework. As mentioned before, in the first iteration, we included all indicators, and consequently excluded one by one until only two most important indicators remained. The results are presented in Table 1.

Table 1: Correlation of evaluated indicators with the I-distance values

\begin{tabular}{|c|c|c|c|c|c|c|}
\hline Smart City Indicators & Iteration1 & Iteration2 & $* * *$ & Iteration7 & Iteration8 & Iteration9 \\
\hline V4 & 0.567 & 0.637 & $* * *$ & 0.685 & 0.704 & 0.806 \\
\hline V8 & 0.644 & 0.626 & $* * *$ & 0.761 & 0.788 & 0.795 \\
\hline V9 & 0.494 & 0.489 & $* * *$ & 0.566 & 0.636 & \\
\hline V5 & 0.534 & 0.493 & $* * *$ & 0.508 & & \\
\hline V1 & 0.423 & 0.469 & $* * *$ & & & \\
\hline V2 & 0.394 & 0.393 & $* * *$ & & & \\
\hline V3 & 0.427 & 0.455 & $* * *$ & & & \\
\hline V6 & 0.296 & 0.282 & $* * *$ & & & \\
\hline V10 & 0.455 & 0.409 & $* * *$ & & & \\
\hline V7 & 0.189 & & $* * *$ & & & \\
\hline average r & 0.442 & 0.473 & $* * *$ & 0.630 & 0.709 & 0.801 \\
\hline
\end{tabular}

Source: Authors' calculation

\section{Results and discussion}

The results of the employed post hoc I-distance approach enabled us to stress out indicators that are crucial for ranking of the 50 selected countries. In particular, the two most important factors are Financial Incentives and Innovation Ecosystem. Financial incentives are closely connected with Build-own-operate (BOO) in developing smart cities ( $\mathrm{Li}$ et al., 2015). Since smart cities are part of an open innovation ecosystem (Schaffers et al., 2012; Letaifa, 2015), it embraces the indicators of knowledge-intensive activities, institutions for cooperation and learning (Li et al., 2016; Scuotto et al., 2016). 
Olga Bogdanov et al. $\bullet$ Scrutinizing the Smart City Index: a multivariate statistical...

Table 2: Changes in rank through I-distance iterations, first and third quartile (Q1 and Q3), median rank and IQR (interquartile range) for selected cities

\begin{tabular}{|c|c|c|c|c|c|c|c|c|c|c|}
\hline City & Rank1 & Rank2 & $* * *$ & Rank7 & Rank8 & Rank9 & Q1 & Median & Q3 & IQR \\
\hline London & 1 & 1 & $* * *$ & 1 & 1 & 1 & 1 & 1 & 1 & 0 \\
\hline Singapore & 2 & 2 & $* * *$ & 2 & 2 & 3 & 2 & 2 & 2 & 0 \\
\hline San Francisco & 5 & 6 & $* * *$ & 3 & 4 & 8 & 3 & 4 & 6 & 3 \\
\hline New York & 3 & 3 & $* * *$ & 5 & 6 & 2 & 3 & 5 & 5 & 2 \\
\hline Montreal & 9 & 8 & $* * *$ & 4 & 5 & 5 & 4 & 5 & 6 & 2 \\
\hline Amsterdam & 10 & 9 & $* * *$ & 6 & 3 & 4 & 6 & 6 & 8 & 2 \\
\hline Columbus & 8 & 5 & $* * *$ & 13 & 24 & 11 & 5 & 7 & 11 & 6 \\
\hline Shanghai & 7 & 7 & $* * *$ & 9 & 18 & 14 & 7 & 9 & 14 & 7 \\
\hline Helsinki & 4 & 4 & $* * *$ & 8 & 15 & 9 & 8 & 9 & 11 & 3 \\
\hline Washington, DC & 16 & 12 & $* * *$ & 10 & 7 & 26 & 8 & 10 & 12 & 4 \\
\hline$* * *$ & $* * *$ & $* * *$ & $* * *$ & $* * *$ & $* * *$ & $* * *$ & $* * *$ & $* * *$ & $* * *$ & $* * *$ \\
\hline Tokyo & 17 & 13 & $* * *$ & 23 & 21 & 31 & 10 & 13 & 21 & 11 \\
\hline Boston & 15 & 18 & $* * *$ & 7 & 12 & 20 & 10 & 13 & 15 & 5 \\
\hline Seoul & 6 & 11 & $* * *$ & 11 & 19 & 27 & 11 & 13 & 14 & 3 \\
\hline Vienna & 13 & 14 & $* * *$ & 26 & 40 & 40 & 14 & 16 & 26 & 12 \\
\hline Hong Kong & 18 & 15 & $* * *$ & 16 & 9 & 6 & 15 & 16 & 17 & 2 \\
\hline$* * *$ & $* * *$ & $* * *$ & $* * *$ & $* * *$ & $* * *$ & $* * *$ & $* * *$ & $* * *$ & $* * *$ & $* * *$ \\
\hline Berlin & 29 & 34 & $* * *$ & 17 & 11 & 18 & 18 & 21 & 29 & 11 \\
\hline Taipei & 23 & 22 & $* * *$ & 20 & 14 & 22 & 22 & 22 & 23 & 1 \\
\hline Tel Aviv & 33 & 28 & $* * *$ & 14 & 8 & 7 & 14 & 25 & 28 & 14 \\
\hline New Delhi & 32 & 31 & $* * *$ & 45 & 45 & 45 & 39 & 40 & 45 & 6 \\
\hline Bhubaneswar & 40 & 40 & $* * *$ & 41 & 44 & 44 & 38 & 40 & 41 & 3 \\
\hline Philadelphia & 44 & 41 & $* * *$ & 31 & 30 & 34 & 34 & 41 & 44 & 10 \\
\hline Jakarta & 46 & 45 & $* * *$ & 42 & 41 & 41 & 41 & 42 & 42 & 1 \\
\hline Dubai & 43 & 39 & $* * *$ & 46 & 46 & 46 & 41 & 43 & 46 & 5 \\
\hline Wellington & 41 & 42 & $* * *$ & 49 & 49 & 49 & 42 & 44 & 49 & 7 \\
\hline Pune & 38 & 44 & $* * *$ & 47 & 47 & 47 & 42 & 44 & 47 & 5 \\
\hline Reykjavik & 42 & 49 & $* * *$ & 39 & 38 & 38 & 39 & 45 & 47 & 8 \\
\hline Paris & 47 & 46 & $* * *$ & 40 & 39 & 39 & 40 & 46 & 46 & 6 \\
\hline Lyon & 45 & 43 & $* * *$ & 50 & 50 & 50 & 45 & 46 & 50 & 5 \\
\hline Phuket & 49 & 47 & $* * *$ & 44 & 43 & 42 & 43 & 47 & 48 & 5 \\
\hline Kigali & 48 & 48 & $* * *$ & 36 & 36 & 36 & 36 & 48 & 48 & 12 \\
\hline Rio de Janeiro & 50 & 50 & $* * *$ & 43 & 42 & 43 & 43 & 50 & 50 & 7 \\
\hline
\end{tabular}

Source: Authors' calculation 
Also, from the results (see Table 2), it is notable that London and Singapore have exhibited consistent ranking throughout the iterations and have a strong showing for each of the analysed factors. Since the introduction of Singapore's Smart Nation initiative (Hoe, 2016; Ho, 2017), Singapore elevated to the level of leading cities/ countries in terms of embracing the smart city axioms and implemented it in the mindset of its citizens (Marsal-Llacuna et al., 2015; Bhati et al., 2017). Among the top 10 cities, one can note considerable fluctuations of the ranks for Columbus and Shanghai. Columbus (USA, Ohio) won the Smart City Challenge in 2016, with its proposal to transform its mobility landscape (Lee and Miller, 2018). Columbus aimed at improving the connectivity and safety of its citizens while at the same time reducing pollution. It was done by promoting the adoption of electric vehicles, multimodal trip planning, parking management and smart mobility hubs (Qi and Shen, 2019). Since Columbus has been recently named a smart city (Abbas, 2017), an in-depth analysis of its performance might shed additional light on the indicators that need to be enhanced.

\section{Conclusion}

Smart cities represent a topic of great concern, not only for researchers and policymakers but dominantly for the general public and its wellbeing. The literature identifies several components that need to function in synergy: infrastructure based on state-of-the-art ICT, human, social and environmental components. Besides, smart governance is an essential factor in the sustainability of smart cities. The paper gives an overview of all components that are important for smartness, but mainly social component - interactions among citizens and human capital (smart people). Limitations of our research partly come from the relative novelty of the topic. Status and even definition of the smart city changes with high dynamics, and we have a limited dataset for our analysis. Secondly, the limitation of our research is the lack of analysis of mutual relation between the factors, mostly in synergetic effects of different combinations. Thirdly, our study analyses a relatively static snapshot of the smart cities. Analysis of time-series data will give new insights into the topic. In future research, we will focus on the synergy among the observed components as a system factor for the success of the smart city and extend our dataset beyond $2018^{\text {th }}$ results.

Since the smart cities represent a multidimensional concept, it encompasses indicators and factors which can be integrated into a single value using the composite indicators framework. The contribution of our research is given in the numerical analysis and determination of relative importance of the most important indicators for the smart city. In practice, our analysis could provide city decisionmakers with the guidelines on where to focus their activities, incentives and priorities. In that sense, this paper contributes to the body of research that strived 
to address the issue of creating and validating a composite indicator of smart cities. Results pointed out those cities which lead the field in terms of implementation of smart cities policies. In future directions of study, by the application of cluster analysis, it is possible to provide a clear benchmark goal (Petrović et al., 2014; Petrović et al., 2018) for each of the observed city.

\section{References}

Abbas, R. A. (2017) A comparison of smart city indicators for three top ten US cities MSc thesis, Faculty of the Graduate School of the University of Texas.

Aguaded-Ramírez, E. (2017). "Smart city and Intercultural Education", ProcediaSocial and Behavioral Sciences, 237, pp. 326-333, http://doi.org/10.1016/j. sbspro.2017.02.010.

Albino, V., Berardi, U., \& Dangelico, R. M. (2015). Smart cities: Definitions, dimensions, performance, and initiatives, Journal of urban technology, 22(1), 3-21.

Allam, Z. and Newman, P., (2018). "Redefining the smart city: Culture, metabolism and governance", Smart Cities, Vol. 1, No. 1, pp. 4-25, http://doi.org/10.3390/ smartcities 1010002.

Alkis, N., Çaldag, M. T., Gokalp, E. (2019) “An Integrated Holistic Success Model for Evaluating Smart City Initiatives". In Proceedings on the International Conference on Internet Computing (ICOMP) (pp. 16-21). The Steering Committee of The World Congress in Computer Science, Computer Engineering and Applied Computing (WorldComp).

Anand, P. B., Navío-Marco, J. (2018) "Governance and economics of smart cities: opportunities and challenges”, Telecommunications Policy, Vol.42, No.10, pp. 795-799, http://doi.org/10.1016/j.telpol.2018.10.001.

Anthopoulos, L.G., Reddick, C.G. (2016, April)" Smart City and Smart Government: Synonymous or Complementary?", In Proceedings of the 25th International Conference Companion on World Wide Web (pp. 351-355). International World Wide Web Conferences Steering Committee.

Anttiroiko, A. V., Valkama, P., Bailey, S. J. (2014) "Smart cities in the new service economy: building platforms for smart services. AI \& society", Vol. 29, No. 3, pp. 323-334, http://doi.org/https://doi.org/10.1007/s00146-013-0464-0.

Appio, F. P., Lima, M., \& Paroutis, S. (2019) "Understanding Smart Cities: Innovation ecosystems, technological advancements, and societal challenges", Technological Forecasting and Social Change, 142, pp.1-14, http://doi.org/ 10.1016/j.techfore.2018.12.018.

Azzari, M. et al. (2018, May) "Smart City Governance Strategies to Better Move Towards a Smart Urbanism", In International Conference on Computational Science and Its Applications (pp. 639-653). Springer, Cham. 
Batagan, L. (2011) "Smart cities and sustainability models", Informatica Economică, Vol. 15, No. 3, pp. 80-87.

Becker, W., Saisana, M., Paruolo, P., Vandecasteele, I. (2017) "Weights and importance in composite indicators: Closing the gap", Ecological indicators, Vol. 80, pp. 12-22.

Bhati, A., Hansen, M., Chan, C. M. (2017). "Energy conservation through smart homes in a smart city: A lesson for Singapore households", Energy Policy, Vol. 104, pp. 230-239, http://doi.org/10.1016/j.enpol.2017.01.032.

Bojkovic, N., Jeremic, V., Petrovic, M., Tica, S. (2019) "Preferences for car sharing service attributes among university students: Evidence from an emerging market", JEEMS Journal of East European Management Studies, Vol. 24, No. 4, pp. 636-653, http://doi.org/10.5771/0949-6181-2019-4-636.

Bouzguenda, I., Alalouch, C., Fava, N., (2019). "Towards Smart Sustainable Cities: A Review of the Role Digital Citizen Participation Could Play in Advancing Social Sustainability", Sustainable Cities and Society, p.101627, http://doi. org/10.1016/j.scs.2019.101627.

Brundtland, G. H. (1987) "Our common future-Call for action", Environmental Conservation, Vol. 14. No. 4, pp. 291-294, http://doi.org/10.1017/s0376892900016805.

Capdevila, I., Zarlenga, M. I. (2015). "Smart city or smart citizens? The Barcelona case”, Journal of Strategy and Management, Vol. 8, No. 3, pp. 266-282, http:// doi.org/10.1108/jsma-03-2015-0030.

Caragliu, A., Del Bo, C., Nijkamp, P., (2011) "Smart cities in Europe", Journal of urban technology, Vol. 18, No. 2, pp. 65-82, http://doi.org/10.1080/10630732.20 11.601117.

Cardullo, P., Kitchin, R. (2019) Being a 'citizen'in the smart city: up and down the scaffold of smart citizen participation in Dublin, Ireland. GeoJournal, Vol. 84, No. 1, pp. 1-13.

Černá, M., Svobodová, L., Hruša, P. (2017, November) "Selected Composite Indicators in the Field of Advanced Technologies and the Internet as a Support of SMART Cities and Their Impact on Tourism", In Conference on e-Business, e-Services and e-Society (pp. 194-205). Springer, Cham.

Chamoso, P. et al. (2018) "Tendencies of technologies and platforms in smart cities: a state-of-the-art review. Wireless Communications and Mobile Computing, Vol. 2018, http://doi.org/10.1155/2018/3086854.

Cocchia, A. (2014) Smart and digital city: A systematic literature review. In Smart city (pp. 13-43). Springer, Cham.

Cudanov, M., Tornjanski, V., \& Jasko, O. (2019) "Change equation effectiveness: empirical evidence from South-East Europe", E\&M Economics and Management, Vol. 22. Iss. 1, pp. 99-114, http://doi.org/10.15240/tul/001/2019-1-007.

Decancq, K., Lugo, M. A. (2013)'Weights in multidimensional indices of wellbeing: An overview", Econometric Reviews, Vol. 32, No.1, pp. 7-34, http://doi.org/10.1 080/07474938.2012.690641. 
de Wijs, L., Witte, P., \& Geertman, S. (2016) "How smart is smart? Theoretical and empirical considerations on implementing smart city objectives-a case study of Dutch railway station areas" Innovation: The European Journal of Social Science Research, Vol. 29, Iss. 4, pp. 424-441, http://doi.org/10.1080/13511610 .2016.1201758.

Dustdar, S., Scekic, O. (2018, July) "On Managing the Social Components in a Smart City." In 2018 IEEE 38th International Conference on Distributed Computing Systems (ICDCS) (pp. 1159-1163). IEEE.

Dobrota, M., Bulajic, M., Bornmann, L., \& Jeremic, V. (2016) “A new approach to the QS university ranking using the composite I-distance indicator: Uncertainty and sensitivity analyses", Journal of the Association for Information Science and Technology, 67(1), pp. 200-211.

Eden Strategy Institute (2018) Top 50 Smart City Governments. Eden Strategy Institute. Available at: https://static1.squarespace.com/static/5b3c517fec4eb 767a04e73ff/t/5b513c57aa4a99f62d168e60/1532050650562/Eden-OXD_ Top $+50+$ Smart+City+Governments.pdf (Accessed: May 5, 2019).

Edelenbos, J., van Meerkerk, I., Koppenjan, J. (2017) "The challenge of innovating politics in community self-organization: The case of Broekpolder". Public Management Review, Vol. 19 Iss. 1, pp. 55-73, http://doi.org/10.1080/1471903 7.2016.1200663.

Edvinsson, L. (2006) "Aspects on the city as a knowledge tool", Journal of knowledge management, Vol. 10, No. 5, pp. 6-13, http://doi.org/10.1108/13673270610691134.

El Gibari, S., Gómez, T., Ruiz, F. (2019). "Building composite indicators using multicriteria methods: a review", Journal of Business Economics, Vol. 89, No. 1, pp. 1-24.

Engelbert, J., van Zoonen, L., Hirzalla, F. (2019) "Excluding citizens from the European smart city: The discourse practices of pursuing and granting smartness", Technological Forecasting and Social Change, Vol. 142, pp. 347353, http://doi.org/10.1016/j.techfore.2018.08.020.

Ercoskun, O. Y. (Ed.). (2011). Green and Ecological Technologies for Urban Planning: Creating Smart Cities: Creating Smart Cities. IGI Global.

Floridi, M., Pagni, S., Falorni, S., Luzzati, T. (2011) An exercise in composite indicators construction: Assessing the sustainability of Italian regions. Ecological economics, Vol. 70 Iss. 8, pp. 1440-1447, http://doi.org/10.1016/j. ecolecon.2011.03.003.

Fratianni, M. and Savona, P. (2016) Sustaining global growth and development: G7 and IMF governance. Routledge.

Giambona, F., Vassallo, E. (2014) "Composite indicator of social inclusion for European countries”, Social Indicators Research, Vol. 116, No.1, pp. 269-293, http://doi.org/10.1007/s11205-013-0274-2. 
Girardi, P., Temporelli, A. (2017) "Smartainability: a methodology for assessing the sustainability of the smart city", Energy Procedia, Vol. 111, pp. 810-816, http:// doi.org/10.1016/j.egypro.2017.03.243

Glaeser, E. L., Berry, C. R. (2006) "Why are smart places getting smarter." Rappaport Institute/Taubman Center Policy Brief, 2.

Goel, N., Kumar, M. (2018) "IOT Review: Building Smart City \& Smart Environment", International Journal for Research in Engineering Application \& Management (IJREAM) Vol. 4, No. 5, pp. 619-625.

Goldin, C. (2016). Human capital. Handbook of cliometrics, pp. 55-86.

Greco, S., Ishizaka, A., Tasiou, M., \& Torrisi, G. (2019) "On the methodological framework of composite indices: A review of the issues of weighting, aggregation, and robustness", Social Indicators Research, Vol. 141, No.1, pp. 61-94, http://doi.org/10.1007/s11205-017-1832-9

Hammad, R., \& Ludlow, D. (2016, December). "Towards a smart learning environment for smart city governance". In Proceedings of the 9th International Conference on Utility and Cloud Computing (pp. 185-190). ACM.

Han, H., Hawken, S. (2018) "Introduction: Innovation and identity in next-generation smart cities", City, culture and society, Vol. 12, pp. 1-4, http://doi.org/10.1016/j. ccs.2017.12.003.

Heijlen, R., Crompvoets, J., (2019) “The smart city of Leuven.” In Smart City Emergence (pp. 83-104). Elsevier.

Ho, E. (2017) "Smart subjects for a Smart Nation? Governing (smart) mentalities in Singapore", Urban Studies, Vol. 54, No.13, pp. 3101-3118, http://doi. org/10.1177/0042098016664305.

Hoe, S. L. (2016) "Defining a smart nation: the case of Singapore", Journal of Information, Communication and Ethics in Society, Vol. 14, No. 4, pp. 323333, http://doi.org/10.1108/jices-02-2016-0005.

Ismagilova, E. et al. (2019) "Smart cities: Advances in research-An information systems perspective", International Journal of Information Management, Vol. 47, pp. 88-100, http://doi.org/10.1016/j.ijinfomgt.2019.01.004.

Ivanovic, B. (1973) "A method of establishing a list of development indicators" Paris: United Nations educational, scientific and cultural organization.

Jednak, S., Kragulj, D., \& Bulajic, M. (2018) "A comparative analysis of development in Southeast European countries", Technological and Economic Development of Economy, 24(1), 253-270.

Jeekel, H. (2017) "Social sustainability and smart mobility: Exploring the relationship", Transportation Research Procedia, Vol. 25, pp. 4296-4310.

Jeremic, V. et al. (2011) "A fresh approach to evaluating the academic ranking of world universities", Scientometrics, Vol. 87, No. 3, pp. 587-596, http://doi.org/ 10.1007/s11192-011-0361-6. 
Jeremic, V., \& Martic, M. (2015) “Assessing the Sensitivity of Hybrid ARWU-THE University Rankings Methodology: The Posthoc I-Distance Approach.” In TREND 2015 Conference, Zlatibor, Serbia.

Jeremic, V., Maricic, M., Bulajic, M. (2018) Benchmarking the AAI performance of EU countries using the post hoc I-distance approach. Poster at Second International Seminar on the Active Ageing Index, Bilbao, Spain, UNECE.

Jovanovic, M., Jeremic, V., Savic, G., Bulajic, M., \& Martic, M. (2012). "How does the normalization of data affect the ARWU ranking?", Scientometrics, 93(2), pp. 319-327.

Koutitas G. (2018) "The Smart Grid: Anchor of the Smart City", Smart Cities: Applications, Technologies, Standards, and Driving Factors, pp. 53-74.

Kumar, H., Singh, M. K., Gupta, M. P. (2016) "Smart governance for smart cities: a conceptual framework from social media practices" In Conference on e-Business, e-Services and e-Society (pp. 628-634). Springer, Cham.

Lagravinese, R., Liberati, P., Resce, G. (2019) "Measuring Health Inequality in US: A Composite Index Approach", Social Indicators Research, Online First, pp. 1-26, http://doi.org/10.1007/s11205-019-02177-x.

Lee, J., \& Miller, H. J. (2018) "Measuring the impacts of new public transit services on space-time accessibility: An analysis of transit system redesign and new bus rapid transit in Columbus, Ohio, USA", Applied geography, 93, pp. 47-63.

Letaifa, S. B. (2015) "How to strategize smart cities: Revealing the SMART model", Journal of Business Research, Vol. 68, No. 7, pp. 1414-1419, http:// doi.org/10.1016/j.jbusres.2015.01.024.

Li, Y., Lin, Y., Geertman, S. (2015, July) "The development of smart cities in China". In Proc. of the 14th International Conference on Computers in Urban Planning and Urban Management (pp. 7-10).

Li, F., Nucciarelli, A., Roden, S., \& Graham, G. (2016) "How smart cities transform operations models: a new research agenda for operations management in the digital economy", Production Planning \& Control, Vol. 27, No. 6, pp. 514-528.

Liu, D., Huang, R., Wosinski, M. (2017) Smart learning in smart cities. Lecture Notes in Educational Technology.

Lombardi, P., Giordano, S., Farouh, H., Yousef, W. (2012) "Modelling the smart city performance", Innovation: The European Journal of Social Science Research, Vol. 25, Iss. 2, pp. 137-149, http://doi.org/10.1080/13511610.2012.660325.

Maricic, M., Egea, J. A., Jeremic, V. (2019) “A hybrid enhanced Scatter SearchComposite I-Distance Indicator (eSS-CIDI) optimization approach for determining weights within composite indicators", Social Indicators Research, Vol. 144, No. 2, pp. 497-537, http://doi.org/10.1007/s11205-018-02056-X.

Marković, M. Zdravković, S., Mitrović, M., \& Radojičić, A. (2016) “An iterative multivariate post hoc I-distance approach in evaluating OECD Better Life 
Index”, Social Indicators Research, Vol. 126, No. 1, pp. 1-19, http://doi.org/ 10.1007/s11205-015-0879-8.

Marsal-Llacuna, M. L., Colomer-Llinàs, J., Meléndez-Frigola, J. (2015) "Lessons in urban monitoring taken from sustainable and livable cities to better address the Smart Cities initiative", Technological Forecasting and Social Change, Vol. 90, pp. 611-622.

Marsa-Maestre, I. et al. (2008) "Mobile agents for service personalization in smart environments", Journal of Networks, Vol. 3, No. 5, pp. 30-41, http://doi. org/10.4304/jnw.3.5.30-41.

Matos, F. et al. (2017) "Increasing smart city competitiveness and sustainability through managing structural capital", Journal of Intellectual Capital, Vol. 18, No. 3, pp. 693-707, http://doi.org/10.1108/jic-12-2016-0141.

Mazziotta, M., Pareto, A. (2016) "On a generalized non-compensatory composite index for measuring socio-economic phenomena", Social Indicators Research, Vol. 127, No. 3, pp. 983-1003.

Milenkovic, M. J., Brajovic, B., Milenkovic, D., Vukmirovic, D., \& Jeremic, V. (2016) Beyond the equal-weight framework of the Networked Readiness Index: a multilevel I-distance methodology. Information Development, Vol. 32, No. 4, pp. 1120-1136, http://doi.org/10.1177/0266666915593136.

Monfaredzadeh, T., Krueger, R. (2015).’Investigating social factors of sustainability in a smart city", Procedia Engineering, Vol. 118, pp. 1112-1118, http://doi. org/10.1016/j.proeng.2015.08.452.

Mussi, F., Tortato, U. (2018) "Cooperation, the Crowding Out Effect and the Role Of Incentives in the Case of Sustainable Hydroplant Project in Brazil" Management: Journal Of Sustainable Business And Management Solutions In Emerging Economies, Vol. 23, Iss. 2, pp. 71-84, http://doi.org/10.7595/ management.fon.2018.0011.

Nam, T., Pardo, T. A. (2011) "Conceptualizing smart city with dimensions of technology, people, and institutions." In Proceedings of the 12th annual international digital government research conference: digital government innovation in challenging times (pp. 282-291). ACM.

Nardo, M. et al. (2005) Handbook on constructing composite indicators: Methodology and User Guide. OECD Statistics Working Papers, No. 2005/03, OECD Publishing, Paris, http://doi.org/10.1787/533411815016.

Nur, M.N.A., Musaruddin, M., Zulkaida, W.O., (2018).”Concept of Smart City for Education: A Case Study in Kendari, Southeast Sulawesi". KnE Social Sciences, Vol. 3, No. 11, pp. 1558-1565.

OECD (2015)."'he Innovation Imperative: Contributing to Productivity, Growth and Well-Being, OECD Publishing, Paris, http://doi.org/10.1787/9789264239814en. 
Oliveira, Á., Campolargo, M. (2015, January). "From smart cities to human smart cities." In 2015 48th Hawaii International Conference on System Sciences (pp. 2336-2344). IEEE.

Osborne, S. P. (2018) From public service-dominant logic to public service logic: are public service organizations capable of co-production and value cocreation? Public Management Review, Vol. 20, Iss. 2, pp. 225-231, http://doi.or $\mathrm{g} / 10.1080 / 14719037.2017 .1350461$.

Papastamatiou, I. et al. (2017) "A decision support framework for smart cities energy assessment and optimization", Energy Procedia, Vol. 111, pp. 800-809.

Petrović, M., Bojković, N., Anić, I., Stamenković, M., \& Tarle, S. P. (2014) “An ELECTRE-based decision aid tool for stepwise benchmarking: An application over EU Digital Agenda targets", Decision Support Systems, 59, pp. 230-241.

Petrović, M., Bojković, N., Stamenković, M., \& Anić, I. (2018) "Supporting performance appraisal in ELECTRE based stepwise benchmarking model", Omega, 78, pp. 237-251.

Pollesch, N. L., \& Dale, V. H. (2016) "Normalization in sustainability assessment: Methods and implications", Ecological Economics, Vol. 130, pp. 195-208.

Poletti, C., Michieli, M. (2018) "Smart cities, social media platforms and security: online content regulation as a site of controversy and conflict." City, Territory and Architecture, Vol. 5, pp. 20, http://doi.org/10.1186/s40410-018-0096-2.

Pultrone, G. (2014) "Participation and governance for more human smart cities", Tema. Journal of Land Use, Mobility and Environment, 7(2), 159-172.

Qi, W., Shen, Z. J. M. (2019) "A Smart-City Scope of Operations Management", Production and Operations Management, Vol. 28, No. 2, pp. 393-406, http:// doi.org/10.1111/poms.12928.

Radojicic, M., Savic, G., \& Jeremic, V. (2018) "Measuring the efficiency of banks: the bootstrapped I-distance GAR DEA approach", Technological and Economic Development of Economy, 24(4), pp. 1581-1605.

Radojicic, M., Jeremic, V., \& Savic, G. (2019) Going beyond health efficiency: What really matters?. The International Journal of Health Planning and Management, http://doi.org/10.1002/hpm.2914.

Rafaj, O., (2016) "Cities and human capital", in $6^{\text {th }}$ Winter Seminar of Regional Science Society for Regional Science and Policy - Slovak Section of ERSA. Available at http://ersa.sk/Zbornik/files/Rafaj.pdf (Accessed 16.8.2019)

Rizzo, F., Deserti, A. (2014, June) "Small scale collaborative services: the role of design in the development of the human smart city paradigm." In International Conference on Distributed, Ambient, and Pervasive Interactions (pp. 583-592). Springer, Cham.

Robinson, J. (2004) "Squaring the circle? Some thoughts on the idea of sustainable development”, Ecological economics, Vol. 48, No. 4, pp. 369-384. 
Rondinella, T., Grimaccia, E. (2017) "Joint Analysis of Structural Models and Performance: Merging Clustering and Composite Indicators in the Analysis of Europe 2020 Strategy" In Complexity in Society: From Indicators Construction to their Synthesis (pp. 323-332). Springer, Cham.

Ruiz-Romero, S., Colmenar-Santos, A., Mur-Pérez, F., López-Rey, Á. (2014) "Integration of distributed generation in the power distribution network: The need for smart grid control systems, communication and equipment for a smart city-Use cases". Renewable and sustainable energy reviews, Vol 38, pp. 223 234, http://doi.org/10.1016/j.rser.2014.05.082.

Saisana, M., Tarantola, S. (2002) State-of-the-art report on current methodologies and practices for composite indicator development (p. 214). Ispra, Italy: European Commission, Joint Research Centre, Institute for the Protection and the Security of the Citizen, Technological and Economic Risk Management Unit.

Sánchez-González, C., \& García-Fernández, R. M. (2019) “A Multivariate Indicator to Compute Middle Class Population", Social Indicators Research, Online First, pp. 1-14, http://doi.org/10.1007/s11205-019-02144-6.

Savić, D., Jeremic, V., Petrovic, N. (2016) "Rebuilding the pillars of sustainable society index: A multivariate post hoc I-distance approach." Problemy Ekorozwoju, Vol. 12, No. 1, pp. 125-134, http://doi.org/10.1007/s11205-015-0879-8.

Schaffers, H. et al. (2011, May) "Smart cities and the future internet: Towards cooperation frameworks for open innovation." In The future internet assembly (pp. 431-446). Springer, Berlin, Heidelberg.

Schaffers, H. et al. (2012) Landscape and roadmap of future internet and smart cities. s. Retrieved from https://hal.inria.fr/hal-00769715/document.

Scholl, H.J., Scholl, M.C. (2014). "Smart governance: A roadmap for research and practice." In IConference 2014 Proceedings.

Scuotto, V., Ferraris, A., Bresciani, S. (2016) "Internet of Things: Applications and challenges in smart cities: a case study of IBM smart city projects", Business Process Management Journal, Vol. 22, No. 2, pp. 357-367.

Senge, P. M. (2006) The fifth discipline: The art and practice of the learning organization. New York: Currency doubleday.

Shapiro, J. M. (2006) "Smart cities: quality of life, productivity, and the growth effects of human capital", The review of economics and statistics, Vol. 88, No. 2, pp. 324-335, http://doi.org/10.1162/rest.88.2.324.

Sharma, V., Guttoo, D., Ogra, A. (2014) "Next generation citizen centric e-services". In 2014 IST-Africa Conference Proceedings (pp. 1-15). IEEE.

Silva, B. N., Khan, M., Han, K. (2018) "Towards sustainable smart cities: A review of trends, architectures, components, and open challenges in smart cities". Sustainable Cities and Society, Vol. 38, pp. 697-713, http://doi.org/10.1016/j. scs.2018.01.053. 
Snieska, V., Zykiene, I. (2014) "The role of infrastructure in the future city: Theoretical perspective" Procedia-Social and Behavioral Sciences, Vol. 156, pp. 247-251, http://doi.org/10.1016/j.sbspro.2014.11.183.

Vanolo, A. (2014) "Smartmentality: The smart city as disciplinary strategy", Urban studies, Vol. 51, No. 5, pp. 883-898, http://doi.org/10.1177/0042098013494427.

Vidiasova, L., Kachurina, P., Cronemberger, F. (2017). "Smart cities prospects from the results of the world practice expert benchmarking", Procedia computer science, Vol. 119, pp. 269-277.

Vlasenko, L., Ivanova, I. (2017) "Urbanization processes and practices of smart city as factors influencing youth's social values." In MATEC Web of Conferences (Vol. 106, pp. 01020). EDP Sciences.

von Richthofen, A., Tomarchio, L., Costa, A. (2019) "Identifying Communities within the Smart-Cultural City of Singapore: A Network Analysis Approach", Smart Cities, Vol. 2, No. 1, pp. 66-81, http://doi.org/10.3390/smartcities2010005.

Winters, J.V., (2011) "Why are smart cities growing?", Who moves and who stays. Journal of regional science, Vol. 51, No. 2, pp. 253-270, http://doi.org/10.1111/ j.1467-9787.2010.00693.x.

Yiftachel, O., Hedgcock, D. (1993) "Urban social sustainability: the planning of an Australian city", Cities, Vol. 10, No. 2, pp. 139-157.

Yigitcanlar, T. et al. (2018) “Understanding 'smart cities': Intertwining development drivers with desired outcomes in a multidimensional framework". Cities, Vol. 81, pp. 145-160, http://doi.org/10.1016/j.cities.2018.04.003.

Yigitcanlar, T., Kamruzzaman, M. (2018) "Does smart city policy lead to sustainability of cities?", Land Use Policy, Vol. 73, pp. 49-58, http://doi. org/10.1016/j.landusepol.2018.01.034.

Zhang, L. P., Zhou, P. (2018) "A non-compensatory composite indicator approach to assessing low-carbon performance", European Journal of Operational Research, Vol. 270, No. 1, pp. 352-361, http://doi.org/10.1016/j.ejor.2018.02.058. 


\title{
Proučavanje indeksa pametnih gradova: multivarijantni statistički pristup
}

\author{
Olga Bogdanov ${ }^{1}$, Veljko Jeremić ${ }^{2}$, Sandra Jednak ${ }^{3}$, Mladen Čudanov ${ }^{4}$
}

\begin{abstract}
Sažetak
Koncept pametnog grada često se obrađuje, ali još nije postignuta konzistentna definicija. Ipak, svaki je opis gotovo uvijek usmjeren na njegovu tehnološku komponentu, politike održivog razvoja i omogućavanje visokih kapaciteta za učenje $i$ inovacije. Osim toga, pametni grad ima za cilj povezivanje ljudi, informacija i drugih gradskih elemenata koristeći najsuvremenije tehnologije. Kao rezultat, stvara se održivi, zeleniji grad, potiče konkurentna i inovativna trgovina $i$ povećava opća kvaliteta života.Integriranim prikazom pametnog grada ističe se da ne djeluje izolirano, te stoga, svaki podsustav grada treba razvijati svoju pametnu komponentu. Sirok raspon rangiranja koristi se za određivanje pametnosti gradova mapiranjem prednosti $i$ nedostataka svakog analiziranog grada. Kao način integriranja različitih pokazatelja u jednu vrijednost koja će predstavljati rang, najčešće se koristi složeni indeksni pristup.Ipak, složeni indeksi najčešće se formiraju primjenom pristupa jednakih pondera, što se u trenutnoj literaturi žestoko kritizira. U ovom radu pokušavamo pružiti dodanu vrijednost indeksu Smart City primjenom statističkog post-hoc I-distance pristupa. Postupak nam omogućuje osvjetljavanje pitanja osjetljivosti ranga gradova. Primjena post-hoc I-distance definira pokazatelje koji su najvažniji za postupak rangiranja što gradskim donositeljima odluka omogućava da poboljšaju svoje poslovanje, s naglaskom na upravo te pokazatelje.
\end{abstract}

Ključne riječi: post-hoc I-distance, pametan grad, održivi razvoj, tehnologija, integracija

JEL klasifikacija: C38, O18, O30

${ }_{1}$ Magistrandica, Univerzitet u Beogradu, Multidisciplinarni studiji, Rektorski ured, Ulica Studentskog Trga 1, 11000 Beograd, Srbija. Znanstveni interes: održivi razvoj, javne politike, socio-ekonomski razvoj. Tel.: +38162592822.E-mail: olgabogdanov94@gmail.com.https:// orcid.org/0000-0001-7933-377X.

2 Izvanredni profesor, Univerzitet u Beogradu, Fakultet organizacionih nauka, Ulica Jove Ilica 154, 11000 Beograd, Srbija. Znanstveni interes: primjenjena statistika, kompozitni indikatori. Tel.: +381113950800.E-mail:veljko.jeremic@fon.bg.ac.rs.http://orcid.org/0000-0002-02665247.

${ }^{3}$ Izvanredna profesor, Univerzitet u Beogradu, Fakultet organizacionih nauka, Ulica Jove Ilica 154, 11000 Beograd, Srbija. Znanstveni interes: ekonomski razvoj, IKT ekonomija, ekonomija zasnovana na znanju, ekonomija energetike. Tel.: +381113950800. E-mail: sandra.jednak@ fon.bg.ac.rs. http://orcid.org/0000-0001-7265-1249.

4 Izvanredni profesor, Univerzitet u Beogradu, Fakultet organizacionih nauka, Ulica Jove Ilica 154, 11000 Beograd, Srbija. Znanstveni interes: organizacijska teorija i dizajn, modeli poslovanja, uticaj informacijskih i komunikacijskih tehnologija na organizaciju. Tel.: +381113950800. E-mail: mladen.cudanov@fon.bg.ac.rs.https://orcid.org/0000-0001-6895-6525. 